\title{
PENGARUH PENGEMASAN DENGAN PLASTIK POLYPROPYLENE DENGAN BERBAGAI LUBANG PERFORASI TERHADAP KUALITAS SIMPAN KANGKUNG (Ipomea reptans Poir.)
}

\author{
Alvira Tuttan Dwi Maharani *, Yoga Aji Handoko, dan Wamilia Yulianingsih \\ Fakultas Pertanian dan Bisnis \\ Universitas Kristen Satya Wacana \\ Gedung Dipo 66 Jalan, Diponegoro 66 Salatiga 50711 \\ *sandituttantuttan@gmail.com
}

\begin{abstract}
Abstrak
Besarnya jumlah dari produksi kangkung tidak diimbangi dengan penanganan pascapanen yang memadai sehingga banyak kangkung yang terbuang dan busuk sebelum diolah karena kangkung termasuk sayuran yang mudah rusak (perishable). Sehingga perlu dilakukan pengolahan lebih lanjut sehingga untuk meningkatkan kesegaran dan menambah nilai ekonomis dari kangkung itu sendiri. Tujuan dari penelitian untuk mengetahui pengaruh pengemasan plastik PP (Polypropylene) dengan berbagai lubang perforasi terhadap warna dan kelayuan kangkung. Metode yang digunakan dalam penelitian ini adalah metode RAL (Rancangan Acak Lengkap) untuk ulangan dilakukan sebanyak 5 kali dengan perlakuan pemberian lubang perforasi : $\mathrm{P}_{0}$ (kontrol), $\mathrm{P}_{1}$ (4 lubang perforasi), $\mathrm{P}_{2}$ (6 lubang perforasi), dan $\mathrm{P}_{3}$ (8 lubang perforasi) dengan perlakuan suhu ruang. Pada penelitian ini didapatkan bahwa dari hasil sidik ragam menunjukan perlakuan terendah terjadi pada perlakuan kontrol terhadap hasil warna dan kelayuan, sedangkan pengemasan dengan plastik PP dengan perlakuan pengemasan 4 lubang dan 8 lubang memberikan hasil terbaik pada warna dan tekstur kangkung.
\end{abstract}

Kata Kunci : Kangkung, Polypropylene, Perforasi, Pascapanen, Respirasi.

Submit: 7 April 2021 * Revisi: 28 April 2021 *Accepted: 5 Mei 2021 * Publish: 10 Mei 2021 


\section{PENDAHULUAN}

Tanaman kangkung merupakan famili Convolvulaceae dimana memiliki ciri-ciri berbatang kecil, bulat, berongga. Tanaman kangkung darat termasuk tanaman sayuran yang berumur pendek. Kandungan gizi dalam 100 g kangkung meliputi energi sebesar $29 \mathrm{kal}$, protein 3 g, lemak 0,3 g karbohidrat 5,4 g, serat 1 gram, kalsium $73 \mathrm{mg}$, fosfor $50 \mathrm{mg}$, besi $2,5 \mathrm{mg}$, vitamin A $6.300 \mathrm{IU}$, vitamin B1 0,07 mg, Vitamin C $32 \mathrm{mg}$, air 89,7 g (Purwadi, 2017).

Produksi kangkung di Indonesia terbilang relatif tinggi. Menurut Badan Pusat Statistik (BPS) (2019) jumlah produksi kangkung di Indonesia pada tahun 2019 sebesar 295.556 ton. Tetapi besarnya jumlah produksi kangkung tidak diimbangi dengan penanganan pascapanen yang memadai sehingga banyak kangkung yang terbuang dan busuk sebelum diolah karena kangkung termasuk sayuran yang mudah rusak (perishable) (Laila, 2017).

Menurut Ambuko et al. (2017) tanaman kangkung yang bersifat mudah rusak akan menyebabkan kehilangan kesegaran akibat proses transpirasi dan respirasi. Transpirasi merupakan tahap fisiologi dimana tanaman akan melepaskan $\mathrm{H}_{2} \mathrm{O}$ dan mengalami penguapan, sehingga pada tanaman akan mengalami susut bobot, kehilangan kandungan $\mathrm{H}_{2} \mathrm{O}$, dan penurunan kesegaran. Menurut Sarifah (2002) respirasi merupakan suatu tahapan dimana tanaman akan menyerap oksigen dan mengeluarkan karbondioksida, air, dan energi untuk mempertahankan metabolisme serta reaksi-reaksi yang terjadi pada jaringan tanaman.

Besarnya jumlah produksi kangkung menyebabkan harga kangkung relatif murah, sehingga perlu dilakukan penanganan pascapanen yang baik untuk mempertahankan kesegaran sayur kangkung serta menjaga agar tetap menjaga nilai ekonomis dari sayur kangkung. Beberapa metode pengelolaan pascapanen seperti pengemasan termodifikasi kangkung (Ipomoea reptans) terolah minimal dengan tipe kemasan stretch film dan pengemasan dengan bahan kemas plastik pada suhu ruang dan dingin dan pengemasan dengan beberapa jenis plastik telah dilakukan (Sugiarto, 2017; Mareta, dkk, 2011). Demikian juga metode dalam perlakuan pascapanen untuk mempertahankan mutu kualitas dan penyimpanan pada kangkung dapat dilakukan dengan mengurangi terjadinya respirasi dengan pengemasan dengan berbagai lubang perforasi (Fransisica, dkk, 2019). Kriteria pengemasan pada kangkung memiliki beberapa persyaratan antara lain: memiliki kemampuan menjaga permeabilitas yan tinggi terhadap gas, bersifat transparan, memiliki desain yang layak, mampu menekan penurunan kerusakan apabila komoditas mengerut, dan memiliki lubang perforasi yang dapat mengatur sirkulasi (Nofriati, 2013).

Menurut Anggraini et al. (2017), pengemasan dengan bahan yang baik akan menghindari sayuran kangkung berkontak langsung baik dengan karbondioksida, oksigen, dan uap air yang mengakibatkan kankung mengalami kelayuan, perubahan warna pigmen daun, susut bobot, dan hilangnya kekerasan kangkung. Pemanfaatan plastik PP (Polypropylene) denga berbagai lubang perforasi diharapkan dapat mengatur sirkulasi air, karbondioksida, dan oksigen sehingga menghambat penurunan mutu kualitas, sehingga perlakuan pengemasan dengan lubang perforasi dapat memperpanjang masa simpan dan kualitas dari tanaman kangkung. 
Tujuan dari penelitian untuk mengetahui pengaruh pengemasan plastik PP (Polypropylene) dengan berbagai lubang perforasi terhadap warna dan kelayuan kangkung.

\section{METODOLOGI PENELITIAN}

\section{Alat dan Bahan}

Bahan yang digunakan dalam penelitian ini kangkung darat, label nama dan plastik polypropylene. Alat yang digunakan pelubang kertas dan steples.

\section{Rancangan Percobaan}

Penelitian dilakukan di kediaman pribadi mulai tanggal 25 Februari hingga 1 Maret 2021. Metode yang digunakan dalam penelitian ini adalah metode RAL (Rancangan Acak Lengkap) untuk ulangan dilakukan sebanyak 5 kali dengan perlakuan pemberian lubang perforasi : $\mathrm{P}_{0}$ (kontrol), $\mathrm{P}_{1}$ (4 lubang perforasi), $\mathrm{P}_{2}$ (6 lubang perforasi), dan
$\mathrm{P}_{3}$ (8 lubang perforasi) dengan perlakuan suhu ruang.

\section{Prosedur Eksperimen}

Kangkung yang diambil di pekarangan rumah pada tanggal 26 Februari 2021. Untuk metode kerja dilakukan dengan proses panen, sortasi, pencucian akar pada kangkung, selanjutnya perlakuan dilakukan dengan plastik PP dilubangi sesuai dengan jumlah lubang perforasi 4,6 , dan 8 dan diletakan pada suhu ruang. Pengamatan dilakukan pada hari ke-2, ke-4, dan ke-6.

\section{Parameter pengamatan}

Digunakan parameter kualitatif berupa parameter warna dan kelayuan kangkung. Pengamatan warna dan kelayuan Pengamatan dilakukan dengan mengamati secara langsung warna dan kelayuan pada kangkung yang telah diberi perlakuan pengemasan dengan lubang perforasi hasil pengamatan dicatat skoring warna dan kelayuan dapat dilihat pada Tabel 1.

Tabel 1. Skoring Warna dan Kelayuan.

\begin{tabular}{|c|c|c|c|}
\hline No & Parameter & Indikator & Skor \\
\hline \multirow{3}{*}{1} & \multirow{3}{*}{ Warna } & Hijau Penuh & 3 \\
\hline & & Hijau Kekuningan & 2 \\
\hline & & Kuning & 1 \\
\hline \multirow{3}{*}{2} & \multirow{3}{*}{ Kelayuan } & Tidak Layu & 3 \\
\hline & & Setengah Layu & 2 \\
\hline & & Layu & 1 \\
\hline
\end{tabular}

\section{HASIL DAN PEMBAHASAN}

Pascapanen komoditas hortikultura adalah merupakan komoditas hidup yang masih aktif melakukan aktifitas metabolismenya. Hal tersebut dapat dicirikan dengan adanya proses respirasi dan transpirasi yang masih terjadi seperti halnya sebelum komoditas tersebut dipanen. Keragaman akan laju respirasi dan transpirasi dalam proses pascapanennya dapat dijadikan sebagai indikator tingkat laju kemunduran dari komoditas tersebut.

Menurut Anggraini et al. (2017) pengemasan dengan plastik polyprolyene 
dapat mempengaruhi dengan mengurangi respirasi dan transpirasi dibandingkan dengan kontrol dimana sifatnya permeabilitas terhadap uap air dan udara tersebut menyebabkan peran plastik dalam memodifikasi ruang kemas selama penyimpanan. Sifat terpenting bahan kemasan yang digunakan meliputi permeabilitas gas dan uap air, bentuk dan permukaannya. Untuk menghindari kemungkinan kerusakan akibat akumulasi $\mathrm{CO} 2$ dan penyusutan $\mathrm{O} 2$ atau kemungkinan yang tidak diinginkan karena dalam kemasan yang rapat, oksigen bebas akan terpakai habis dalam waktu singkat

\section{Warna}

Warna daun pada tanaman kangkung dipengaruhi adanya klorofil yang menyebabkan daun berwarna hijau.
Menurut Sudjatha dan Wisaniyasa (2017) terjadinya perubahan warna dapat diindikasi adanya penurunan kandungan klorofil pada daun. Penyebab terjadinya degradasi klorofil dikarenakan adanya perubahan enzim oksidatif, pada $\mathrm{pH}$ pada jaringan tanaman dan munculnya enzim khlorofilase. Klorofil akan dipecah oleh enzim klorofilase menjadi fitol dan inti forfirin. Klorofil dapat kehilangan magnesiumnya yang terdapat pada gugus porfirinnya, sehingga akan berubah menjadi feofitin. Akibatnya terjadi perubahan warna. Pada ada hasil pengamatan parameter warna dari berbagai perlakuan dapat dilihat pada Tabel 2. Kemudian hasil sidik ragam dapat dilihat pada Tabel 3. Rata-rata hasil parameter warna dapat dilihat pada Gambar 1.

Tabel 2. Hasil Pengamatan Parameter Warna dari Berbagai Perlakuan.

\begin{tabular}{|c|c|c|c|c|c|c|c|}
\hline \multirow[b]{2}{*}{ Perlakuan } & \multicolumn{5}{|c|}{ Hasil kelayuan Berbagai Perlakuan } & \multirow{2}{*}{$\begin{array}{l}\text { Jumlah } \\
\text { hasil } \\
\text { perlakuan }\end{array}$} & \multirow{2}{*}{$\begin{array}{c}\text { Rataan } \\
\text { Hasil } \\
\text { Perlakuan }\end{array}$} \\
\hline & $\begin{array}{c}\text { Ulangan } \\
1\end{array}$ & $\begin{array}{c}\text { Ulangan } \\
2\end{array}$ & $\begin{array}{c}\text { Ulangan } \\
3\end{array}$ & $\begin{array}{c}\text { Ulangan } \\
4\end{array}$ & $\begin{array}{c}\text { Ulangan } \\
5\end{array}$ & & \\
\hline Kontrol & 1,333 & 2 & 2 & 2 & 1,33 & 8,667 & $1,73 \mathbf{a}$ \\
\hline 4 lubang & 2,333 & 2 & 2,333 & 2,333 & 2,33 & 11,33 & $2,27 \mathbf{b}$ \\
\hline 6 lubang & 2 & 2 & 2 & 2 & 2 & 10 & $2 \mathbf{a b}$ \\
\hline 8 lubang & 2,333 & 2 & 2 & 2 & 2,33 & 10,67 & $2,13 \mathbf{b}$ \\
\hline \multicolumn{6}{|c|}{ Jumlah Umum (G) } & 40,67 & \\
\hline \multicolumn{6}{|c|}{ Rataan Umum } & & 8,13 \\
\hline
\end{tabular}

Keterangan : Angka-angka dengan huruf kecil pada kolom menunjukan perbedaan nyata berdasarkan uji BNJ pada taraf 5\%

Tabel 3. Hasil Analisis Sidik Ragam dengan Ulangan yang Sama terhadap Warna pada Kangkung.

\begin{tabular}{|c|c|c|c|c|c|}
\hline \multirow{2}{*}{$\begin{array}{c}\text { Sumber } \\
\text { Keragaman }\end{array}$} & \multirow{2}{*}{$\begin{array}{l}\text { Jumlah } \\
\text { Kuadrat }\end{array}$} & \multirow{2}{*}{ Kuadrat Tengah } & \multirow{2}{*}{ F Hitung ${ }^{b}$} & \multicolumn{2}{|c|}{ F Tabel } \\
\hline & & & & $5 \%$ & $1 \%$ \\
\hline db Perlakuan & 0,778 & 0,259259 & $5,49 * *$ & 3.24 & 5.29 \\
\hline $\mathrm{db}$ Galat & 0,756 & 0,047222 & & & \\
\hline db Umum & 1,533 & & & & \\
\hline
\end{tabular}

$b^{* *}:$ Perbedaan berbeda sangat nyata pada taraf $1 \%$ 


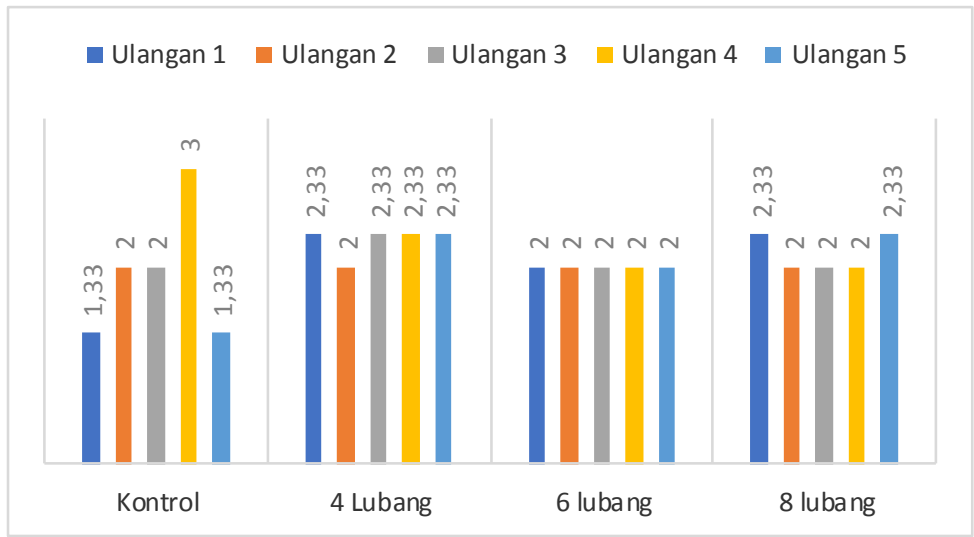

Gambar 1. Rata-Rata Hasil Warna pada Berbagai Lubang Perforasi pada Perlakuan

\section{Pengemasan}

Hasil analisis sidik ragam pada Tabel 3 menunjukan semua perlakuan yang diberikan berbeda sangat nyata terhadap hasil warna. Analisis ragam menunjukan perlakuan pengemasan dengan berbagai lubang perforasi dan kontrol memberikan pengaruh nyata terhadap warna pada kangkung. Hal ini ditunjukan bahwa perlakuan terendah pada perlakuan kontrol sedangkan perlakuan tertinggi pada perlakuan 4 lubang dan 8 lubang perforasi.

Pada perlakuan terendah yaitu kontrol menunjukan adanya perubahan warna akibat adanya respirasi, sehingga semakin banyak lubang perforasi atau tanpa pengemasan maka respirasi semakin meningkat. Hal ini menurut Fransisica et al. (2017) terjadi proses respirasi yang mengakibatkan dihasilkannya energi yang memicu reaksi kerja sehingga memicu proses pematangan pada komoditas. Menurut pendapat Setyaputri et al (2019) bahwa warna pada kangkung dipengaruhi oleh adanya pigmen yang terkandung dalam kangkung, sehingga dengan adanya perubahan warna pada sayur daun berhubungan dengan adanya kerja enzim terhadap pigmen warna klorofil.
Menurunnya kandungan klorofil diakibatkan meningkatnya reaksi enzim klorofilase yang dapat mendegradasi klorofil. Bahwa kloroplas mengalami degradasi lebih dahulu jauh sebelum warna hijaunya hilang dari jaringan. Jadi adanya degradasinya pigmen hijau tersebut menyebabkan pigmen lain muncul karena pigmen ini sebelumnya tertutup oleh pigmen hijau tersebut.

\section{Kelayuan}

Menurut Sudjatha dan Wisaniyasa (2017) adanya kelayuan dapat terjadi dikarenakan terdapat kegiatan respirasi dan fotosintesis menurun karena terjadinya kerusakan mitokondria. Hal ini pada saat proses kelayuan jaringan sel akan melemah/menurun, sehingga terjadi perubahan permeabelitas dari membran sel. Karena proses sintesis protein terhambat, proses kelayuan akan dipercepat. Pada ada hasil pengamatan parameter kelayuan dari berbagai perlakuan dapat dilihat pada Tabel 4 . Kemudian hasil sidik ragam dapat dilihat pada Tabel 5. Rata-rata hasil parameter kelayuan dapat dilihat pada Gambar 2. 
Tabel 4. Hasil Kelayuan dari Berbagai Perlakuan Pengemasan.

\begin{tabular}{|c|c|c|c|c|c|c|c|}
\hline \multirow[b]{2}{*}{ Perlakuan } & \multicolumn{5}{|c|}{ Hasil kelayuan Berbagai Perlakuan } & \multirow{2}{*}{$\begin{array}{c}\text { Jumlah } \\
\text { hasil } \\
\text { perlakuan }\end{array}$} & \multirow{2}{*}{$\begin{array}{c}\text { Rataan } \\
\text { Hasil } \\
\text { Perlakuan }\end{array}$} \\
\hline & $\begin{array}{c}\text { Ulangan } \\
1\end{array}$ & $\begin{array}{c}\text { Ulangan } \\
2\end{array}$ & $\begin{array}{c}\text { Ulangan } \\
3\end{array}$ & $\begin{array}{c}\text { Ulangan } \\
4\end{array}$ & $\begin{array}{c}\text { Ulangan } \\
5\end{array}$ & & \\
\hline Kontrol & 1 & 1 & 1 & 1 & 1 & 5 & $1 \mathbf{a}$ \\
\hline 4 lubang & 2,67 & 2 & 2 & 2,33 & $\begin{array}{c}2,66666 \\
7\end{array}$ & 11,7 & $2,33 \mathbf{b}$ \\
\hline 6 lubang & 2 & 1,67 & 1,67 & 2,67 & $\begin{array}{c}1,66666 \\
7\end{array}$ & 9,67 & $1,93 \mathrm{ab}$ \\
\hline 8 lubang & 3 & 2,67 & 1,67 & 1,67 & $\begin{array}{c}1,66666 \\
7\end{array}$ & 10,7 & $2,13 \mathbf{b}$ \\
\hline \multicolumn{6}{|c|}{$\operatorname{Jumlah} \operatorname{Umum}(\mathrm{G})$} & 37 & \\
\hline \multicolumn{6}{|c|}{ Rataan Umum } & & 7,4 \\
\hline
\end{tabular}

Keterangan : Angka-angka dengan huruf kecil pada kolom menunjukan perbedaan nyata berdasarkan uji BNJ pada taraf $5 \%$

Tabel 5. Hasil Analisis Sidik Ragam dengan Ulangan yang Sama terhadap Kelayuan pada Kangkung.

\begin{tabular}{|lcccccc|}
\hline \multicolumn{1}{c}{ Sumber } & Derajat & Jumlah & Kuadrat & F Hitung $^{\text {b }}$ & \multicolumn{2}{c|}{ F Tabel } \\
Keragaman & Bebas & Kuadrat & Tengah & F & $1 \%$ \\
\hline db Perlakuan & 3 & 5,22 & 1,74 & $9,63^{* *}$ & 3.24 & 5.29 \\
db Galat & 16 & 2,89 & 0,18 & & & \\
db Umum & 19 & 8,11 & & & & \\
\hline
\end{tabular}

$\mathrm{b}^{* *}$ : perbedaan sangat nyata pada taraf $1 \%$

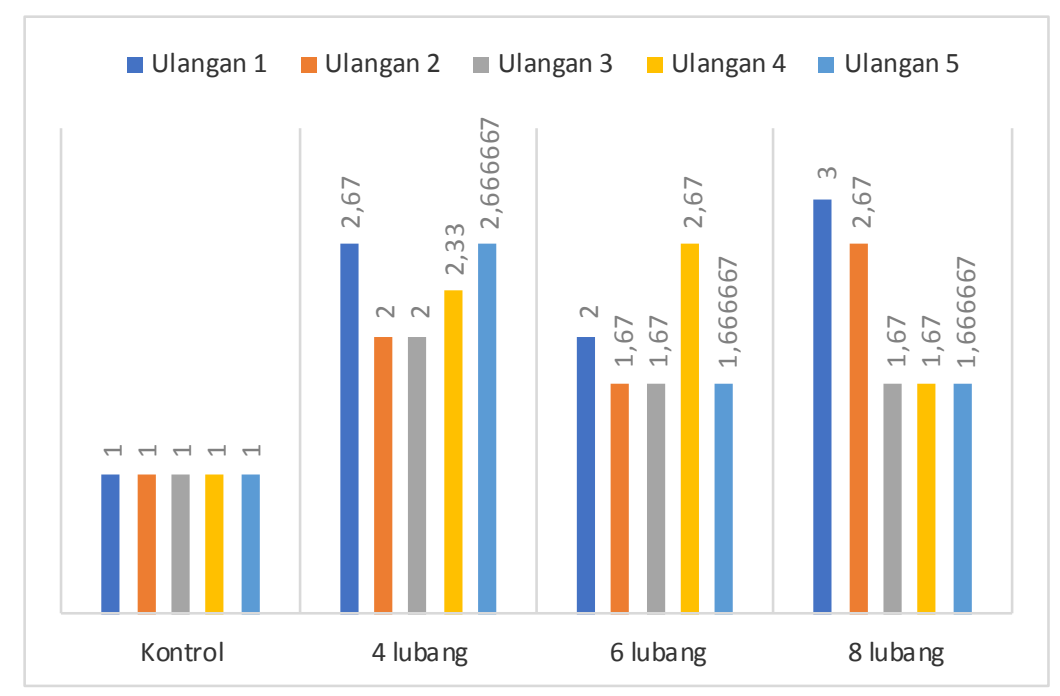

Gambar 2. Rata-Rata Hasil Warna pada Berbagai Lubang Perforasi pada Perlakuan Pengemasan 
Hasil analisis sidik ragam pada Tabel 5 menunjukan bahwa perlakuan yang diberikan memiliki hasil yang berbeda sangat nyata terhadap hasil kelayuan. Analisis ragam menunjukan perlakuan pengemasan dengan berbagai lubang perforasi dan kontrol memberikan pengaruh nyata terhadap kelayuan pada kangkung. Hal ini ditunjukan bahwa perlakuan terendah pada perlakuan kontrol sedangkan perlakuan tertinggi pada perlakuan 4 lubang dan 8 lubang perforasi.

Perlakuan pengemasan dengan plastik PP (Polypropylene) berbagai lubang perforasi dapat menurunkan laju kehilangan $\mathrm{H}_{2} \mathrm{O}$ pada kangkung sehingga dapat mencegah terjadinya kehilangan kandungan air di dalam kangkung. Proses tersebut mengaktifkan enzim dalam sel bahan. Reaksi kerja enzim dapat meningkatkan penguraian zat-zat dalam sel yang disebabkan oleh. Proses hidrolisis akan menghasilkan karbondioksida dan air sehingga dapat meningkatkan kandungan air. Hal ini didukung dengan adanya hasil dari penelitian Singh dan Sagar (2010) hal ini disebabkan karena perlakuan dengan pengemasan dengan lubang perforasi dapat mengurangi konsentrasi oksigen dan akan meningkatkan konsentrasi karbondioksida yang dapat menurunkan laju respirasi dan transpirasi. Sehingga dapat dihambat, semakin sedikit lubang perforasi yang mengatur sirkulasi uap karbondioksida, oksigen dan air dapat lebih baik dan semakin menghambat terjadinya penurunan mutu kualitas (Fransisica, dkk, 2017).

\section{KESIMPULAN DAN SARAN}

\section{Kesimpulan}

Pada penelitian ini didapatkan bahwa dari hasil sidik ragam berpengaruh sangat nyata yang menunjukan pada perlakuan terendah terjadi pada perlakuan kontrol terhadap hasil warna dan kelayuan, sedangkan hasil analisis sidik ragam memberikan pengaruh yang sangat nyata pada pengemasan dengan plastik PP dengan perlakuan pengemasan 4 lubang dan 8 lubang memberikan hasil terbaik pada warna dan tekstur kangkung.

\section{Saran}

Untuk penelitian selanjutnya, terkait perlakuan pengemasan kangkung dengan lubang perforasi sebaiknya menggunakan parameter hasil susut bobot dan perlakuan terbaik didapatkan pengemasan dengan lubang perforasi 4 lubang dan 8 lubang.

\section{DAFTAR PUSTAKA}

Oka, A. A. 2007. Pengaruh Pemberian Pupuk Kascing terhadap Pertumbuhan Tanaman Kangkung Darat (Ipomoea reptans poir). Jurnal Sains MIPA Vol.13 No.1, Tahun 2007. Pp: 26. jurnal.fmipa.unila.ac.id.

Ambuko, J., Wanjiru, F., Chemining'wa, G. N., Owino, W. O., Mwachoni, E. 2017. Preservation of Postharvest Quality of Leafy Amaranth (Amaranthus spp) Vegetables using Evaporative Cooling. Journal of Food Quality. Doi

ArticleID5303156,6.https://doi.org /10.1155/2017/5303156. Diunduh pada tanggal 30 Maret 2021.

Anggraini, R. dan N. D. Permatasari. 2017. Pengaruh Lubang Perforasi dan Jenis Plastik Kemasan terhadap Kualitas Sawi Hijau (Brassica Juncea L.). Jurnal Penelitian Pascapanen Pertanian 
Vol. 14 No.3, Tahun 2017. Pp : 154 162.

ejurnal.litbang.pertanian.go.id

BPS. 2020. Produksi Tanaman Sayuran 2019. www.bps.go.id. Diunduh pada tanggal 4 April 2021.

Fransisica, A., M. Istianto dan G. A. Siregar. 2017. Pengaruh Suhu dan Jumlah Perforasi pada Kemasan terhadap Susut Bobot Kangkung. Jurnal Ilmu Pangan dan Hasil Pertanian Vol.3 No. 1, Tahun 2017. journal.upgris.ac.id

Laila, K. 2017. Pendugaan Umur Simpan Tepung Kangkung (Ipomoea reptans) Menggunakan Metode Arrhenius. Skripsi. Fakultas Teknologi Pertanian, Universitas Andalas. Padang

Mareta, D. T. dan S. Nur. 2011. Pengemasan Produk Sayuran dengan Bahan Kemas Plastik pada Penyimpanan Suhu Ruang dan Suhu Dingin. Jurnal Mediagro Vol.7 No.2, Tahun 2011. Pp : 26 40 publikasiilmiah.unwahas.ac.id

Muchtadi, D. 1992. Fisiologi Pasca Panen Sayuran dan Buah-buahan. Bogor : IPB Press.

Nofriati, D. 2013. Teknologi Pasca Panen Sayur Daun. Jambi : Balai Pengkajian Teknologi Pertanian (BPTP) Jambi.
Purwadi, W. 2017. Pertumbuhan dan Kadar Protein pada Tanaman Kangkung Darat (Ipomoea reptans poir) dengan Pemberian Pupuk Organik Cair (POC) Berbahan Dasar Sabut Kelapa dan Limbah Cair Tahu. Surakarta : UMS.

Sarifah, N. 2002. Kajian Laju Respirasi dan Produksi Etilen sebagai Dasar Penentuan Waktu Simpan Sayuran dan Buah-Buahan. Jurnal Bionatura Vol. 4 No. 3, Tahun 2002 pp: 148-156. jurnal.unpad.ac.id Setyaputri, N. A., dan T. D. Kurnia. 2019. Pengaruh Pelapisan Kitosan dan Perlakuan Pengemasan terhadap Masa Simpan Brokoli (Brassica oleracea var. Italica). Jurnal Agrosaintek Vol. 3 No.2, Tahun 2019. Pp : 67 -72. agrosainstek.ubb.ac.id

Singh, U dan V. R. Sagar. 2010. Quality Characteristic of Dehydrated Leafy Vegetables Influenced by Packing Material And Storage Temperature. J. Sci. \& Ind Vol.69 No.1 2010. semanticscholar.org.

Sugiarto. 2017. Pengemasan Termodifikasi Kangkung (Ipomea reptans) Terolah Minimal dengan Tipe Kemasan Stretch Film. Bogor : IPB Press. 